Mots. Les langages du politique

\title{
The Euroregional discourse. Increasing evidence towards legitimizing an institutional space
}

Le discours eurorégional. Indices convergents de légitimation d'un espace institutionnel

El discurso eurorregional. Indicios convergentes de legitimación institucional

Marie-Hélène Hermand

\section{(2) OpenEdition}

\section{Journals}

Electronic version

URL: https://journals.openedition.org/mots/21839

DOI: $10.4000 /$ mots. 21839

ISSN: 1960-6001

This article is a translation of:

Le discours eurorégional. Indices convergents de légitimation d'un espace institutionnel - URL :

https://journals.openedition.org/mots/21793 [fr]

Publisher

ENS Éditions

Printed version

Date of publication: 31 December 2014

ISBN: 978-2-84788-544-6

ISSN: 0243-6450

\section{Electronic reference}

Marie-Hélène Hermand, "The Euroregional discourse. Increasing evidence towards legitimizing an institutional space", Mots. Les langages du politique [Online], 106 | 2014, Online since 31 December 2016, connection on 23 April 2022. URL: http://journals.openedition.org/mots/21839 ; DOI: https:// doi.org/10.4000/mots. 21839

This text was automatically generated on 23 April 2022

(C) ENS Éditions 


\title{
The Euroregional discourse. Increasing evidence towards legitimizing an institutional space
}

\author{
Le discours eurorégional. Indices convergents de légitimation d'un espace \\ institutionnel \\ El discurso eurorregional. Indicios convergentes de legitimación institucional
}

\author{
Marie-Hélène Hermand
}

1 We have chosen to compare different Euroregional discourses in the context of a research project on an increasingly visible form of European communication. These "cross-border co-operation structures between contiguous European territories" ${ }^{1}$ with a potential impact on Europe's future, provide a distinct opportunity to capture the subtle expression of a European space currently facing serious challenges.

2 Through the analysis of institutional statements, which is the purpose of the present article, we hope to identify the elements contributing to the development of a discourse presenting the Euroregion as the essential configuration of the future Europe. The analysis will also highlight the correlation with commitments to legitimize cross-border cooperation as expressed in 1980 in the Madrid Charter ${ }^{2}$ and re-affirmed by the European Commission in the preliminary presentation of its 2014-2020 budget: "reinforcing cooperation across borders and making the setting up of more crossborder projects easier". ${ }^{3}$

3 Three potential discursive regularities concerning the Euroregional space have emerged from our first observations: evidence of institutional legitimacy, systematic performance targets and the idealization of the lifestyle offered to border citizens. We will consider the first of these regularities, namely the dynamics of discursive legitimacy of the Euroregional space. In doing so, we will first describe how this discourse fits in its own institutional environment and the development of a multilingual digital corpus, two prerequisites before considering the communication processes of European cross-border areas. 


\section{Inclusion of this discourse in the history of cross- border cooperation}

4 Under its various linguistic guises (Euregio, Eurégio, Eurorégion Europaregion, Regio, etc.), a Euroregion may refer to different structures, from the association of local authorities to public or private law bodies. Often initially self-proclaimed, Euroregions actually originated in transnational cooperation attempts at the end of the Second World War to maintain peace in Europe. ${ }^{4}$ They are usually studied by geographers, legal experts and political scientists and among the latter group some have recently proposed new definitions:

Euroregions can thus be defined as European cross-border and transnational cooperation organisations, more or less structured, bringing together institutions ranging from local to regional authorities or their equivalent, associated to develop a common set of actions or objectives, because of shared interests in "project areas".

[Les eurorégions peuvent ainsi se définir comme des organisations européennes de coopération transfrontalière et transnationale, plus ou moins structurées, regroupant des autorités territoriales allant en général de la commune à la région ou à leurs équivalents, associées pour la réalisation d'actions et d'objectifs communs, en fonction d'intérêts partagés et dans le cadre de «territoires de projets ». (Perrin, 2013, p. 7)]

5 Of the 163 border regions in the European Union, ${ }^{5}$ the Council of Europe lists approximately 90 Euroregions which have reaped the fruits of the Association of European Border Regions's lobbying efforts since 1971 (Alliès, 2011). Highlighted in the 1993 Vienna Declaration, ${ }^{6}$ the role of the Euroregions for the democratic stability of the European space is asserted and defended by the European Commission which encourages the funding of cross-border projects with the implementation of the Interreg program. The 1990's witnessed an explicit encouragement of cross-border cooperation policies, the empowerment of the cross-border approach and the multiplication of Euroregions. Accompanying the process of European expansion, the Neighbourhood Policy launched in 2003 by the European Union accentuated this trend further by expanding cross-border arrangements to Central and Eastern Europe.

6 The introduction in 2006 of the European Regulation on EGTC (European Grouping of Territorial Cooperation) by the European Parliament and the Council ${ }^{7}$ has already helped 46 Euroregions achieve an official status while 19 others have introduced an application to be registered. ${ }^{8}$ The EGTC has both a symbolic and legal significance and is integral to the regionalization efforts in Western Europe (Cole, Palmer, 2009) and Eastern Europe (Wassemberg, 2009). Based on the contractual freedom of member regions, it is both an instrument of European cooperation policy and a powerful promoter of the current development of euroregionalism (Marin, 2012). The legally structured Euroregions alone concern over 75 million citizens, a fact little known by the general public. ${ }^{9}$

7 The main political actors are the European Commission, the regions and the Member States. The Community method ${ }^{10}$ regulates the dialogue between these protagonists according to the principles of subsidiarity and partnership that encourage funding cross-border projects and the invention of new models of collaboration between border areas. These forms of support are however hampered by national standards deemed 
contrary to European objectives of unification of border regions (Alliès, 2011) and more generally by the varying degree of commitment of states in cooperation policy (Perrin, 2011). EGTC Regulation, revised in May 2013, now allows for the creation of EGTC with the tacit approval of the involved states, clarifies the legal status of their personnel and offers partnership opportunities to any public company. The initial subordinated relationship has evolved into one of dialogue and negotiation between national and sub-national authorities (Goehrs, 2013).

Whether they already have a formal status or are in the process of acquiring one, Euroregions are the subject of special attention by the European Union and are the locus of new territorial development strategies ${ }^{11}$ and new power configurations. Yet, if they have enjoyed the benefits of increased European budgets dedicated to economic and social cohesion and the strong mobilization of local authorities, ${ }^{12}$ they are now required to communicate professionally with citizens. For these reasons, we believe that reconstructing their various statements which are the basis of their discursive ethos, like a discursive image (Amossy, 1999), provides us with an opportunity to identify the exact stage when cross-border communication, expressed from varied discursive positions in Europe moves from an empirical and informal process to a professional one.

\section{Multilingual proliferation of the Euroregional discourse}

Since the mid 1990s, the Euroregional discourse has accompanied the deployment and visibility of the Euroregions on the web. Widely available, it has proliferated online since 2000, even before the EGTC Regulation was set up. In line with other digital corpora that require digital tools to process them, this discourse opens up vast possibilities of reflexivity, different paths and connectivity of a rich and non-linear content (Rastier, 2011). Besides the digital dimension, the Euroregional discourse does not stop at the linguistic borders to ensure its dissemination within cross-border areas. It is present in several languages which need to be combined in a multilingual corpus to provide a more accurate representation (Scholz, 2010). Finally, the many production contexts must also be taken into account. The corpus originates in institutional, economic and media contexts and was established according to the thematic crawling method (Yapomo, 2013), which consists in identifying separately in each language relevant terminologies referring to the Euroregional theme. Once these various discursive components are assembled around the Euroregional "thematic focus", as recommended by Maingueneau (2012), one can start building homogeneous subcorpora for analysis.

In this article, we have limited the analysis to statements reflecting the Institutional position regarding the Euroregions because they are influenced by a certain "degree of legitimacy" and a "prior image" which belong to a pre-discursive ethos (Amossy, 1999, p. 147). We have thus excluded all other statements made by the numerous economic and media-related actors who describe, narrate or judge the Euroregions.

11 During a first phase, we gathered statements in French and German which we considered to be primary languages because of the historical concentration of Euroregions along the borders of French-speaking countries or regions (France, Belgium, Luxembourg, Swiss Romandie, Aosta Valley in Italy) and German-speaking ones (Germany, Austria, Eastern Belgium, Luxembourg, German-speaking Switzerland, 
Italian South Tyrol). These two languages alone provide us the opportunity to observe many European regions and might supply us with comparison material thanks to the numerous voices arising from countries - such as France and Germany- with contrasted discursive positions on the implementation of European reforms (Angermüller, Scholz, 2013).

In order to widen the scope of the research on this discourse to other European areas where many Euroregions have also developed in recent years, a second phase focused on gathering institutional statements made in English, Dutch, Italian and Spanish. Thus we have a selection of Euroregional discourses from Northern Europe (Netherlands, Denmark, Sweden, Norway, the Baltic countries), North-Western Europe (Ireland, UK), Eastern Europe (Poland, Czech Republic, Slovenia) and Southern Europe (Italy, Greece, Spain, Portugal).

This has helped to gradually improve the visibility of these areas and further the analysis of an already contrasted vision in the context of other comparative studies (von Münchow, Rakotonoelina, 2006). 196 texts $\left(103,853\right.$ words $\left.^{13}\right)$ were drawn together from 32 official websites ${ }^{14}$ which illustrate the institutional discourse of a third of the Euroregions identified by the Council of Europe, in six official languages of the Union.

We have queried this sub-corpus using textometry software ${ }^{15}$ starting with keywords and co-ocurrences. As the automatic morphosyntactic analysis is language-dependent, the results are divided into six monolingual sets before being used as guides or steps towards a qualitative analysis.

15 We identified three conditions to compare the material, which was essential prior to the analysis of authentic documents produced in different languages (Claudel, TreguerFelten, 2006, p.24). These conditions are first the proximity of the contexts of production. By focusing on institutional websites we were able to focus on the statements made by the Euroregions and on how they fashioned their discursive identity. Secondly, the editorial line shared by the Euroregion community, which should be understood as an "institution which is coherent because of its discursive practices" (Beacco, 2004) brings together documents produced in different languages and places: they have consistently presented and promoted Euroregions in the same way institutional websites have, even if we can not entirely prove that the discursive processes were identical. Thirdly, a useful comparison benchmark is provided by the similarity of discursive genres on institutional and Euroregion websites, evidenced by short texts unlikely to change in the short term: the editorial, the welcome message, the mission statement and the brochure.

\section{Discursive legitimacy of the Euroregional space}

The automatic detection of common names shows a recurring interest in the Euroregional institutional discourse for terms referring to spatial configurations. The latter are among the most common occurrences: ${ }^{16}$

Table 1. The most common occurrences in the Euroregional institutional discourse, in descending order (rank 1 corresponds to the most common term)

\begin{tabular}{|l|l|l|l|l|l|l|}
\hline Rank & French & Italian & Spanish & English & German & Dutch \\
\hline
\end{tabular}




\begin{tabular}{|l|l|l|l|l|l|l|}
\hline $\mathbf{1}$ & région & regione & - & region & - & - \\
\hline $\mathbf{2}$ & - & territorio & - & - & Euroregion & - \\
\hline $\mathbf{3}$ & - & - & eurorregión & - & - & - \\
\hline $\mathbf{4}$ & - & euroregione & región & - & Region & euregio \\
\hline $\mathbf{5}$ & eurorégion & - & territorio & area & - & - \\
\hline $\mathbf{6}$ & - & provincia & - & border & Grenzregion & regio \\
\hline $\mathbf{7}$ & territoire & - & - & - & - & provincie \\
\hline $\mathbf{8}$ & - & - & - & - & - & - \\
\hline $\mathbf{9}$ & espace & - & - & - & Europaregion & - \\
\hline
\end{tabular}

17 The cotext then shows that the concept of cross-border area is directly connected in the statements to the European strategy for the future and to the proposed establishment of specific cross-border structures promoted by the European Commission. Touted as a reservoir of practical solutions, Euroregions avoid the reference to the national space, as evidenced by the absence of the words "nation" or "country" in the table. By examining in further detail the enunciative positions and the lexical environment, several similarities with the approach already implemented by the European Union to build support for its discourse (Gobin, Cussó, 2002) can be detected. Anchoring the institutional discourse with reference to an authority figure, neutralizing any polemical aspects and a significant lexical convergence all combine to provide a consensual view of the Euroregional space. We have detailed these three discursive components below.

\section{Reference to an authority figure}

18 The "communication contract" (Charaudeau, Maingueneau, 2002) links the discourse to an ideal public composed mainly of border residents (especially the youth, a recurrent and primary target), institutional and economic partners located along the borders, and occasional visitors, travelling for private or professional reasons. Its validity comes first from the fact that it offers a prior confirmation of the expertise of Euroregional deciders (presidents, administrators, officials). As they often come from regional political spheres, they transfer their decisional abilities to a new geographical, political and economic space. The use of the first person and the reference to a prestigious third-party highlight a "declared authority" (Plantin, 1996) as reminders of a career rooted in the territory, as statements regarding strategic relational networks or as assertions by strong personalities. We highlight the salient points in two examples below:

We have strong personalities: the Belgian Minister of Justice, Stefaan de Clerck, who is also the Mayor of Courtrai, Rudi Demotte, who is the Minister-President of the Walloon Region, born in Tournai, myself, as Vice-President, et then Martine Aubry, president of Lille Metropole Urban Community. ${ }^{17}$ (Gilles Pargneaux, vice-president of the LilleKortrijk-Tournai Eurometropole)

The exceptional position of the Minister of Justice Poppenhäger in European bodies and their associated networks are an important support. ${ }^{18}$ (Franck Rossner, administrator of the Euregio Egrensis) 
Sporadic public speeches provide further details on the performance conditions and the constraints of the contract. Those in charge of its implementation (content editors of the Euroregional websites, operational staff involved in Euroregional projects) undertake, in the present and in the future of the indicative, to meet the readers' presumed orientation expectations (we hope you find your way on our website), as well as information (we will inform you on the website ${ }^{19}$ ) and expected results (we present the first results ${ }^{20}$ ). Information sharing acts as a guarantee of the contract whilst invitations function as cohesive factors between related parties (we would encourage everyone to visit these fabulous two resources in our region ${ }^{21}$ ). It is the action that prevails in the formulations and the challenge is to allow the exercise of authority while ensuring the "consent of the citizen body" (Charaudeau, 2005, p. 14).

\section{Neutralization of the polemical aspects}

20 If one notices tensions in other parts of the corpus (economic and media discourses) regarding the construction of the Euroregional space, the institutional side studied here does not contain this polemical dimension. The domination of determinative adjectives (Dufour, 2012) gives the discourse a consensual tone and is mainly used to specify the geographical or administrative scope (European, territorial, regional) and functional one (political, economic, and scientific) assigned to the Euroregional space: ${ }^{22}$

Table 2. The most frequently found adjectives in the Euroregional institutional discourse

\begin{tabular}{|l|l|l|l|l|l|l|}
\hline Rank & French & Italian & Spanish & English & German & Dutch \\
\hline $\mathbf{1}$ & Européen & europeo & universitario & european & grenzüberschreitend & Engelstalig \\
\hline $\mathbf{2}$ & Territorial & economico & - & cross-border & europäisch & Europees \\
\hline $\mathbf{3}$ & transfrontalière & comune & - & joint & - & - \\
\hline $\mathbf{4}$ & économique & transfrontaliero & europeo & cultural & deutsch & Internationaal \\
\hline $\mathbf{5}$ & - & culturale & - & local & gemeinsam & Duits \\
\hline $\mathbf{6}$ & Politique & - & educativo & regional & regional & - \\
\hline $\mathbf{7}$ & - & regionale & académico & academic & - & - \\
\hline $\mathbf{8}$ & Régional & italiano & científico & - & niederländisch & - \\
\hline $\mathbf{9}$ & métropolitain & - & económico & international & weit & cultureel \\
\hline $\mathbf{1 0}$ & Social & instituzionale & jurídico & national & - & duitstalig \\
\hline
\end{tabular}

21 The combination of the Euroregional configuration to figures (statistics of workers, trainees and apprentices identified in the Euroregions) or to various bodies in charge of producing these figures (statistical offices, interregional observatories) tend to consolidate the indisputable character of the institutional discourse. Associated with a positive vision of the Euroregion, the figures become transformed indicators that highlight the intensity and quality of exchanges within the Euroregions. Maintained for a long time and with the promise of a bright future, these exchanges argue for a dynamic and open Euroregion. The transfer of goods, services and employees helps to ensure the continuity of the Euroregional space conducive to exhanges: exchanges 
hardly ceased, exchanges continued ${ }^{23}$ (Euroregion Mediterranean Alps); such exchange initiatives shall also result in the development and improvement of competence ${ }^{24}$ (Euroregion Baltic); exchange of experience with precursors (Euroregion Neisse-Nisa-Nysa); an information exchange platform ${ }^{25}$ (Euroregion BENEGO); stimulate entrepreneurs through the exchange of experiences ${ }^{26}$ (Scheldemond euroregion)...

The recurring theme of continuity of the Euroregional space also comes from the evocation of a shared past which is sufficient to constitute a solid and welcoming base for the new Euroregional configuration. References to history -already observed in other discursive analyses where a regional entity is exposed as a "natural unit" resulting from the past (Costa and Bert, 2011) - present the Euroregion as the normal evolution of previous harmonious situation: a shared history ${ }^{27}$ (Eurégion Meuse-Rhine), populations that have woven together without interruption over the centuries history ${ }^{28}$ (CrossChannel Euroregion), united by a common history ${ }^{29}$ (Europaregion Tyrol-South TyrolTrentino).

The use of a shared memory is also based on the full valorisation of a multi-millennial heritage (Euroregion Alps-Mediterranean), a common cultural heritage ${ }^{30}$ (Euregio Barents), a landscape heritage ${ }^{31}$ (Scheldemond euroregion) or a common cultural heritage ${ }^{32}$ (EURORegion Elbe-Labe). This reference to a shared and localized heritage recalls the concept of "local heritage" which Utard (2005) questioned both the logical contradiction (concern for the common good versus defending special interests) and symbolic legitimacy (the property can only become a heritage by decision of a body authorized to produce and manage such symbols).

Expressed here from viewpoints outside or superior to those of the constituent regions of the Euroregions, the presentation of shared decisions finally cancels any trace of national reference and rivalry between the regions: the definition of a common vision for the five regions ${ }^{33}$ (Euroregion Alps-Mediterranean); political coordination between the five regions $^{34}$ (Euroregion Pyrenees-Mediterranean); the future of cross-border relations in the region, if we look at this micro-region from an international point of view ${ }^{35}$ (Euroregion EuroBalkans). Clearly, all the Euroregional spaces are melted into a unified and accepted vision with no traces of prior negotiations.

\section{Lexical convergences}

Whilst giving it the appearance of clarity and a decidedly positive turn, the use of imprecise vocabulary tends to neutralise the Euroregional discourse itself and expose its language to the risk of becoming standardised. In places where one would expect specific descriptions of different Euroregional spaces to perceive their identity, the discourse uses instead lexical fields very close to each other. The border areas' history, characteristics, degree of formalization and promotional needs vary widely one from another yet appear to fall into the mould of an undifferentiated communication. Explanations for the idiosyncratic complexity of each Euroregional space often fail in their endeavour. It then becomes difficult to assess the extent to which the Euroregional configuration will apply the problem-solving strategy put forward in its discourse. Relevant and coherent excerpts with the potential to become references provide us with a striking view of the lexical regularity noticeable in the communications of very different Euroregions: 
Table 3. Samples of repeated segments characterizing the notion of Euroregional space

\begin{tabular}{|l|l|l|}
\hline Issuing Euroregion & Language & Repeated segments (English translation) \\
\hline $\begin{array}{l}\text { - Meuse-Rhin } \\
\text { - West-Vlaanderen-Flandre-Dunkerque- } \\
\text { Côte d'Opale } \\
\text { - Grande Région Saar-Lor-Lux }\end{array}$ & French & $\begin{array}{l}\text { territoires pertinents (relevant territories) } \\
\text { espaces de coopération cohérents (coherent } \\
\text { cooperation areas) } \\
\text { territoire de référence (reference territory) }\end{array}$ \\
\hline - Alpi-Mediterraneo & Italian & $\begin{array}{l}\text { spazio unico (unique area) } \\
\text { spazio coerente (coherent area) } \\
\text { spazi eccezionali (exceptional areas) } \\
\text { punto di riferimento (reference points) }\end{array}$ \\
\hline $\begin{array}{l}\text { - Pirineos-Mediterráneo } \\
\text { - Alentejo-Algarve-Andalucía }\end{array}$ & Spanish & $\begin{array}{l}\text { espacio privilegiado (privileged area) } \\
\text { espacio atractivo (attractive space) }\end{array}$ \\
\hline $\begin{array}{l}\text { espacios protegidos (protected area) } \\
\text { espacio complejo (complex area) }\end{array}$ \\
\hline $\begin{array}{l}\text { - Baltic } \\
\text { - East Border Region }\end{array}$ & English & $\begin{array}{l}\text { attractive space } \\
\text { protected area } \\
\text { coherent area } \\
\text { priority area }\end{array}$ \\
\hline - Salzburg-Berchtesgadener \\
Südbohmen
\end{tabular}

The adoption of Euroregional spatial references also requires the occasional reference to the polycentric metropolitan cross-border region, the polycentric spatial development or the polycentric conurbation ${ }^{36}$ (Greater Region). These segments, though few in number, alert us to the potential importance in other parts of the Euroregional corpus to the rhetoric of metropolisation and polycentricism, two terms that reflect well the concept of decisive intervention in a conventionally known area (Allain, 2005).

Reviewing the discursive usage of urban configurations enables us to detect the occasional participation of the city and the capital city in order to legitimise the Euroregional space. First mentioned as a geographical landmark to locate the Euroregion (proximity to major capital cities, ${ }^{37}$ Aix-la-Chapelle is the westernmost largest city ${ }^{38}$ ), the city becomes an important argument in itself to promote the Euroregional space as soon as an activity is associated with it. As a tourist attraction in the Euroregional space (encourages people from both towns to take the opportunity to visit one another ${ }^{39}$ ) and, more broadly, a place of exchange and socialization (guests from "friendly" cities ${ }^{40}$ ), it has the advantage of being a familiar reference for the general public. Other uses of the city, in the context of the implementation of seats ([Euroregion] based in the House of the Greater Region in Luxembourg City) or formal agreements (the Cross-border Cooperation Agreement was signed in the city ${ }^{41}$ ), also contribute to the institutionalization of the Euroregional space. We suggest, therefore, by taking Maingueneau's two concepts $(1999$, p. 79$)$, to consider the urban configuration as a 
"scene" which may facilitate the "incorporation" of the general public's imagination into the community of those who adhere to the Euroregional discourse.

The issue here is the adoption of a reference point other than the one we are used to (the capital within a national space, or the regional capital within a national sub-space) and from which one can situate the concept of "proximity" praised in the Euroregional discourse (in proximity to its citizens, close proximity of densely populated areas, proximity between the public actors, proximity of living areas). Recurrent figures (548,000 inhabitants, 126 inhabitants per square kilometre ${ }^{42}$ ) or urban ranking positions (Turin is the fourth largest city with about 900,000 inhabitants ${ }^{43}$ ) also show that a demographic threshold may enhance the accessibility and encourage mobility (mainly international, professional and student) among Euroregions. From an interdiscursive point of view this concern for mobility evokes the Treaty of Rome ${ }^{44}$ which from 1957 onwards has promoted the free movement of people for mainly professional reasons. From a communication perspective, media practices supported by rankings and the mobility argument have already been observed in the discourses of local authorities (Cardy, 2011) and universities (Angermüller, Scholz, 2013; Gaspard, 2013) in order to promote their performance.

To promote the Euroregional vision sought by European policy, the discourse uses inchoate phrases that illustrate the creation of new spaces (the organization of cities as networks is still in its infancy, [the enlarged Europe] builds interregional spaces of cooperation). Verbs of motion also reflect the opening of formerly enclosed spaces (opens outwards, opens on a multicultural territory at $360^{\circ}$ ), their transformation (becoming an area of crossborder interdependence, following the development of European territories) or their removal (removing borders, eliminating a border). These movements reinforce the perspective which has already been noted of a shift of the main centres in Europe (Alliès, 2011), occurring at the expense of areas conventionally defined by national or regional borders and whose destination is still unclear.

To conclude, we must remember that the Euroregional institutional discourse began as an element of cross-border cooperation policy born after the Second World War. It seeks to establish the relevance of cross-border areas with diverse audiences in mind (inhabitants, youth, partners, visitors) and announces a profound reconfiguration of the European space planned by the European institutions. The multilingual sub-corpus which has been studied here from institutional websites, reflects the positioning of one-third of the Euroregions identified by the Council of Europe. The study of lexical frequency and qualitative analysis of statements referring to the notion of space have identified three discursive regularities: manifestations of authority (visible authority, occasional public speeches), a removal of all polemical aspects (determinative adjectives, peaceful vision of the past) and a clear lexical convergence independent from where the discourse originated (multilingual equivalents of repeated segments). To incorporate the co-enunciator with the emerging communities represented by the Euroregions, the discourse focuses the people's attention by evoking shared experiences (exchanges) and references (cities). By insisting on continued exchanges and a unified vision of history, it smoothes out the differences between Euroregions and attempts to erase a previous situation often marked by border disputes. The 
hypothesis that the Euroregional institutional discourse tends to legitimize itself by erasing ideological national opposition is thereby confirmed. This alleviation of national opposition is not the result of the invention of specific Euroregional identities but rather by standardizing representations: descriptions of Euroregions are almost interchangeable. Now that the institutional legitimacy of the Euroregions is firmly in place, in accordance with European policy, a natural and idealized image of crossborder areas has emerged.

\section{BIBLIOGRAPHY}

ALLAIN Rémy, 2005, « Ville et proximité. Le point de vue d'un géographe-urbaniste », Mots. Les langages du politique, $\mathrm{n}^{\circ} 77$, Proximité, p. 128-136.

ALLIÈs Paul, 2011, « La notion d'Eurorégion et sa mise en œuvre dans l'Union européenne », C. E. Pachedo Amaral éd., Autonomie régionale et relations internationales. Nouvelles dimensions de la gouvernance multilatérale, Paris, L'Harmattan, p. 245-255.

AMOSsy Ruth, 1999, Images de soi dans le discours. La construction de l'ethos, Lausanne, Delachaux et Niestlé.

ANGERMÜLLER Johannes, scholz Ronny, 2013, « Au nom de Bologne? Une analyse comparative des discours politiques sur les réformes universitaires en Allemagne et en France ", Mots. Les langages du politique, $\mathrm{n}^{\circ}$ 102, Les discours sur l'enseignement supérieur et la recherche, p. 20-36.

BEACCO Jean-Claude, 2004, « Trois perspectives linguistiques sur la notion de genre discursif », Langages, vol. XXXVIII, $\mathrm{n}^{\circ}$ 153, p. 109-119.

CARDY Hélène, 2011, « Le discours identitaire dans les politiques de communication territoriale. La place de leur palmarès et de leur médiatisation ", Mots. Les langages du politique, $\mathrm{n}^{\circ} 97$, Les collectivités territoriales en quête d'identité, p. 59-74.

CHARAUDEAU Patrick, 2005, Les masques du pouvoir, Paris, Vuibert.

ChaRAUdeau Patrick, Maingueneau Dominique, 2002, Dictionnaire d'analyse du discours, Paris, Le Seuil, p. 138-141.

CLAUDEL Chantal, TREGUER-FELTEN Geneviève, 2006, « Rendre compte d'analyses comparatives sur des corpus issus de langues/cultures éloignées ", Les Cahiers du Cediscor, $\mathrm{n}^{\circ}$ 9, Discours, cultures, comparaisons, P. von Münchow, F. Rakotonoelina éd., Paris, Presses de la Sorbonne nouvelle, p. 23-37.

COLE Alistair, PALMER Rosanne, 2009, «Logiques de territorialité et de régionalisation en Europe de l'Ouest », Revue d'études comparatives Est-Ouest, vol. XXXIX, p. 19-36.

COSTA James, BERT Michel, 2011, « De l'un et du divers. La région Rhône-Alpes et la mise en récit de ses langues », Mots. Les langages du politique, $\mathrm{n}^{\circ}$ 97, Les collectivités territoriales en quête d'identité, p. 45-57. 
DUFOUR Françoise, 2012, « Développement durable, humain. La cohérence discursive des contradictions ", Mots. Les langages du politique, $\mathrm{n}^{\circ}$ 96, Les discours politiques. Approches interactionnistes et multimodales, p. 81-96.

GASPARD Jeoffrey, 2013, « Le discours promotionnel des universités européennes. Homogénéité dans la compétitivité ? ", Mots. Les langages du politique, $\mathrm{n}^{\circ} 102$, Les discours sur l'enseignement supérieur et la recherche, p. 52-66.

GOBIN Corinne, cussó Roser, 2008, « Du discours politique au discours expert. Le changement politique mis hors débat? ", Mots. Les langages du politique, $\mathrm{n}^{\circ} 88$, Discours politique, discours expert, p. 5-11.

GOEHRS Manuel, 2013, «Le groupement européen de coopération territoriale (GECT), outil contractuel de régulation territoriale ", Jurisdoctoria, $\mathrm{n}^{\circ}$ 9, p. 85-109.

MAINGUENEAU Dominique, 2012, « Que cherchent les analystes du discours ? ", Argumentation et analyse du discours, $n^{\circ}$ 9, p. 2-14. En ligne : http://aad.revues.org/1354 (consulté le 12 mars 2014).

- 1999, «Ethos, scénographie, incorporation », R. Amossy éd., Images de soi dans le discours. La construction de l'ethos, Lausanne, Delachaux et Niestlé, p. 75-100.

MARIN Anaïs, 2012, « Coopérer à travers les frontières orientales de l'UE. Le modèle eurorégional et ses limites ", Regard sur l'Est, n 62, Frontières recomposées à l'Est, en ligne : http://www.regardest.com/home/breve_contenu.php?id=1377 (consulté le 10 mai 2014).

PERRIN Thomas, 2013, Culture et eurorégions. La coopération culturelle entre régions européennes, Bruxelles, Université libre de Bruxelles.

- 2011, « L'institutionnalisation de la coopération transfrontalière en Europe », Ceriscope Frontières, en ligne : http://ceriscope.sciences-po.fr/content/part2/linstitutionnalisation-de-lacooperation-transfrontaliere-en-europe?page=6 (consulté le 19 mai 2014).

PLANTIN Christian, 1996, L'argumentation, Paris, Le Seuil, p. 88-93.

RASTIER François, 2011, La mesure et le grain. Sémantique de corpus, Paris, Honoré Champion, p. 9-52.

scholz Ronny, 2010, « Traiter le multilinguisme dans les discours politiques. Possibilités et limites d'une analyse lexicométrique dans un corpus composé des textes de différentes langues ", intervention au séminaire du 19 mars 2010, Université Paris-Est Créteil Val de Marne (Ceditec). UTARD Jean-Michel, 2005, « Du patrimoine au "proximoine” ou le présent d'une illusion », Mots. Les langages du politique, $\mathrm{n}^{\circ}$ 77, Proximité, p. 137-144.

VON MÜNCHOW Patricia, RAKотоNOELINA Florimond, 2006, Les Cahiers du Cediscor, $\mathrm{n}^{\circ}$ 9, Discours, cultures, comparaisons, Paris, Presses de la Sorbonne nouvelle.

WASSEMBERG Birte, 2009, «Le voisinage de proximité : les eurorégions “géopolitiques" aux frontières externes de l'UE (1993-2009) », Matériaux pour l'histoire de notre temps 1, nº 97-98, p. 45-49.

YAPOMO Manuela, 2013, «Construction de corpus multilingues : état de l'art », Actes de Recital 2013 : $X V^{e}$ Rencontre des étudiants chercheurs en informatique pour le traitement automatique des langues, 17-20 juin 2013, Les Sables d'Olonne, en ligne : http://www.taln2013.org/actes/www/ RECITAL-2013/actes/recital-2013-long-005.pdf (consulté le 13 avril 2014). 


\section{NOTES}

1. European spatial planning glossary (Lexique d'aménagement du territoire européen Université de Paris VII - DATAR - CNRS) (accessed April 5, 2014): http://www.ums-riate.fr/ lexique/modeleterme.php?id=21.

2. European Outline Convention on Transfrontier Co-operation between Territorial Communities or Authorities, or so-called Madrid Charter, was signed in Madrid on May 21, 1980 by the member States of the Council of Europe.

3. European Commission, November 19, 2013 (accessed April 7, 2014): http://europa.eu/rapid/ press-release_MEMO-13-1011_fr.htm.

4. The first Euroregion project was set up in 1958 as the result of disparate initiatives among five regions in Germany and the Netherlands.

5. http://www.aebr.eu/fr/membres/repartition_regionale.php (accessed on April 5, 2014).

6. The Vienna Declaration, signed on October 9, 1993, is accessible on the European Council's website.

7. The Regulation No $1082 / 2006$ of the European Parliament and of the Council of 5 July 2006 on a European grouping of territorial cooperation (EGTC) was published in the Official Journal L 210 July 31, 2006.

8. Its status has developed remarkably since 2010: 6 new EGTC were set up in 2012 and 11 in 2013. See the list of EGTCs (February 5, 2014) in the register kept by the Committee of the Regions (accessed May 29, 2014): https://portal.cor.europa.eu/egtc/en-US/CoRActivities/Pages/ welcome.aspx.

9. EGTC-Follow-up report 2013, accessible on the Committee of the Regions' website (accessed May 29, 2014): http://cor.europa.eu/en/documentation/studies/Documents/EGTC-monitoringreport-2013/EGTC-monitoring-report-2013-exec-sum-FR.pdf.

10. The Community method refers to the institutional functioning of the first pillar of the European Union, i.e. the European communities. It is based on a premise of integration. Its main elements are described on the European Union website (accessed May 19, 2014): http:// europa.eu/legislation_summaries/glossary/community_intergovernmental_methods_fr.htm.

11. Joint Statement at the 13th Summit of the Greater Region, January 24, 2013, p. 7 (accessed April 5, 2014): http://www.granderegion.net/fr/news/2013/01/20130124-13e-sommet-de-lagrande-region/13-SOMMET-DECLARATION-COMMUNE.pdf.

12. According to the European Union's official website, for the period 2007-2013, 8.7 billion euros out of 347 dedicated to European regional policy (the second largest budget after the common agricultural policy) have been spent on territorial cooperation. Plans for the period 2014-2020 include an increased budget for territorial cooperation, i.e. 9.6 billion euros.

13. The 103,853 words of this institutional sub-corpus represent one fifth of our entire Euroregional corpus (about 500,000 words, adding institutional, economic and media-related discourses on the Euroregions).

14. The publication manager and the domain name guarantee the official aspect of our selection of institutional websites.

15. We use the free TXM platform made available by the ANR Textométrie project at the École Nationale Supérieure de Lyon, by connecting the modular component TreeTagger, made available by the University of Stuttgart for multilingual morphosyntactic labelling. We also use custom programs developed in Perl to accelerate multilingual queries and automate the extraction of results from the corpus.

16. The empty cells in the table refer to occurrences that do not fall within the lexical scope of the spatial configuration (e.g. president, project, objective). These occurrences are not mentioned here to ensure an easier reading. 
17. We have personally translated all statements made in foreign languages (Italian, Spanish, English, German, Dutch). The original text is quoted in the footnotes, without further precisions. Here: Nous avons des personnalités fortes : le Ministre belge de la Justice, Stefaan de Clerck, qui est aussi le Bourgmestre de Courtrai, Rudi Demotte, qui est le Ministre-président de la Région wallonne, originaire de Tournai, moi-même, en tant que Vice-président, et puis Martine Aubry, présidente de Lille Métropole Communauté Urbaine.

18. Die hervorragende Position von Justizminister Poppenhäger in den europäischen Gremien und die dazugehörigen Netzwerke sind eine wichtige Unterstützung. Damit übernimmt auch Thüringen einen entscheidenden Gestaltungsanteil.

19. wir werden Sie auf der Webseite informieren

20. presentiamo i primi risultati

21. In the original English (N.T.).

22. Empty cells refer to argumentative adjectives, e.g. nouveau, important, intensivo, good...

23. gli scambi hanno continuato

24. In the Original English (N.T.).

25. een platform voor informatie-uitwisseling

26. door de ervaringsuitwisseling ondernemers te stimuleren

27. une histoire commune

28. des populations qui ont tissé ensemble et sans interruption au fil des siècles leur histoire

29. vereint durch eine gemeinsame Geschichte

30. In the Original English (N.T.).

31. landschappelijk erfgoed

32. Pflege des gemeinsamen kulturellen Erbes

33. la definizione di una visione comune alle cinque regioni

34. una coordinación política entre las cinco regiones

35. In the original English (N.T.).

36. polyzentrischen Verdichtungsraum

37. Arc Manche Region Transmanche.

38. Aachen ist die westlichste Grosstadt (Greater Region).

39. East Border Region.

40. ospiti delle città "amiche" (Euroregione Adriatico-Ionica)

41. se firmaba en la ciudad el Convenio de cooperación transfronteriza (Eurorregión AlentejoAlgarve-Andalucía)

42. Euregion Helsinki-Tallinn.

43. Torino è la quarta città con 900000 abitanti circa (Euroregione Alpi-Mediterraneo)

44. The text of the Treaty of Rome is accessible here: http://www.constitutioneu.eu/ cariboost_files/trait_c3_a9_20de_20rome.pdf.

\section{ABSTRACTS}

From a multilingual corpus composed of institutional websites published by the Euroregions, this article attempts to explore the discursive indications which tend to legitimize the notion of Euroregional area. The lexicometric and qualitative observations lead to a compliance to the 
normative objectives of the European politics and to the standardization of the euroregional representations, in spite of languages and issuing cross-border areas.

À partir d'un corpus de sites web institutionnels publiés par les eurorégions, l'article explore les indices discursifs qui tendent à légitimer la notion d'espace eurorégional. L'analyse lexicométrique et qualitative des énoncés multilingues aboutit au double constat d'une conformité aux objectifs normatifs de la politique européenne et d'une uniformisation des représentations eurorégionales, en dépit des langues et des zones transfrontalières émettrices.

Desde un corpus multilingüe de sitios web institucionales publicados por las eurorregiónes, este artículo explora las pistas discursivas que tienden a legitimar la noción de zona eurorregional. Las observaciónes lexicométricas y cualitativas conducen a una conformidad con los objetivos normativos de la política europea y a la normalización de las representaciones eurorregionales, a pesar de las lenguas y de las áreas geográficas.

\section{INDEX}

Palabras claves: Eurorregión, discurso institucional, corpus multilingüe, comunicación transfronteriza, comunicación europea

Keywords: Euroregion, institutional discourse, multilingual corpus, cross-border communication, European communication

Mots-clés: eurorégions, discours institutionnel, corpus multilingue, communication transfrontalière, communication européenne

\section{AUTHOR}

\section{MARIE-HÉLÈNE HERMAND}

Université libre de Bruxelles, Centre de recherche ReSIC 